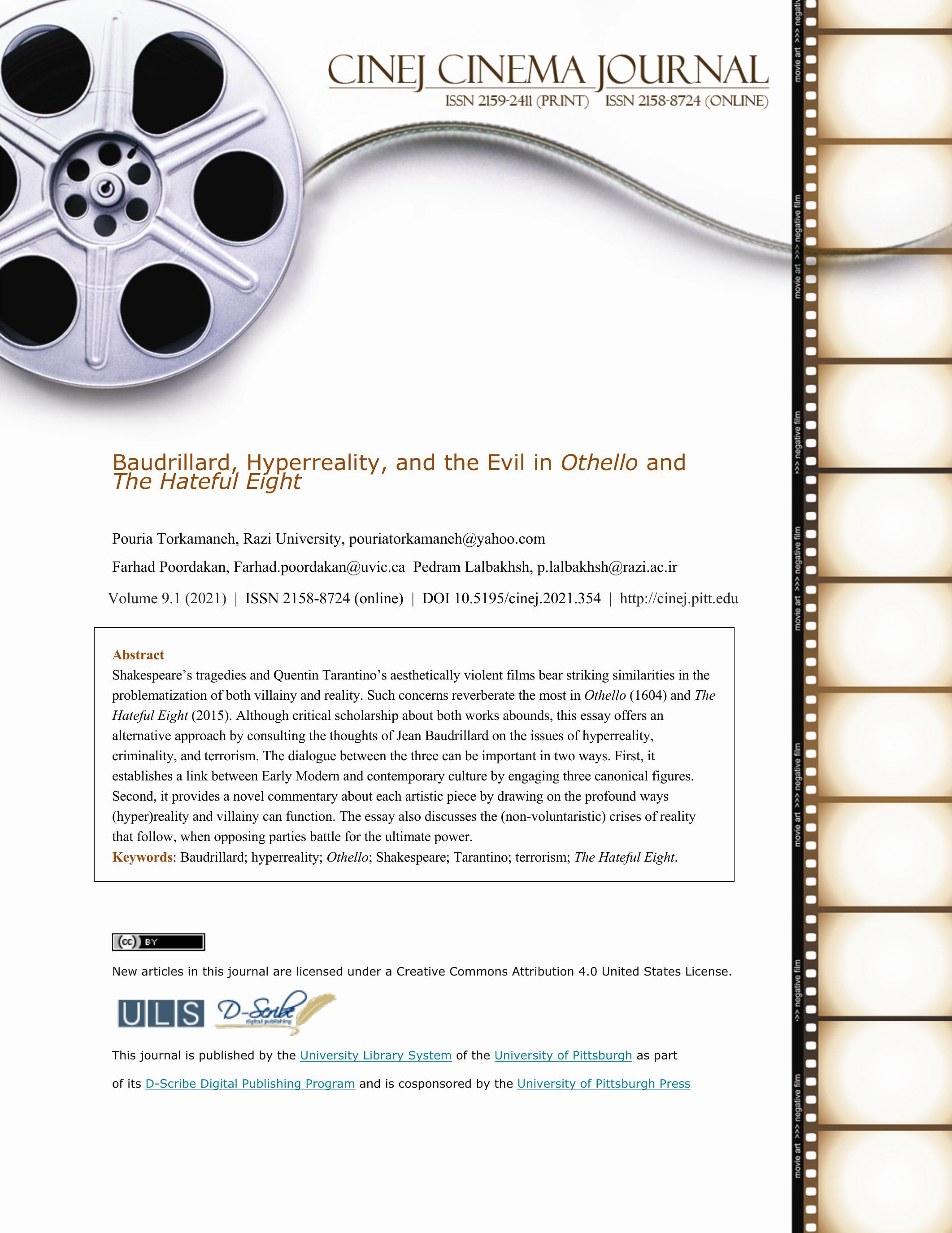





\section{Baudrillard, Hyperreality, and the Evil in Othello and}

\section{The Hateful Eight}

\section{Introduction}

Throughout his twenty-four-year career and with his eight movies, Quentin Tarantino has attracted diverse audiences, ranging from pure thriller-seekers to the highly philosophicalminded. Having begun with Reservoir Dogs in 1992, Tarantino's oeuvre is frequently interpreted as a critique of (American) violence represented in an aesthetically fascinating style. Unsurprisingly, the audience, especially those who pursue his works seriously, have learned to associate Tarantino's name with vulgarly violent protagonists, who might be even unnerving to watch for some viewers. Pointing to the same disconcerting quality of some texts in his classic The Pleasure of the Text, Roland Barthes separates a "text of bliss" from a "text of pleasure" by characterizing the former as:

\footnotetext{
The text that imposes a state of loss, the text that discomforts (perhaps to the point of a certain boredom), unsettles the reader's historical, cultural, psychological assumptions, the consistency of his tastes, values, memories, brings to a crisis his relation with language. $(1975,14)$
}

Two important and interrelated matters arise in this passage: first, a text that moves beyond mere pleasure, "unsettles" and "discomforts" its audience; and second, that Barthes claims that a text of bliss "imposes" restrictions upon the "consistency" of what we consider the corporeal reality of our (quotidian) actions. Even though this study does not seek to explore Tarantino's film(s) in light of textual studies, Barthes' contention that a work of art can shake our perception of reality can prove thought-provoking in analyzing other forms of art. 
Tarantino and Shakespeare. An unlikely pairing, perhaps, but our common interest in both figures and cross-genre/medium research drove this essay to a comparative study of The Hateful Eight and Othello. Such a comparative reading can be "premised on the idea that media inevitably bear on one another's traces" (Geiger and Littau 2013, 2) - that no medium can be understood fully in isolation, be it cinema, drama or philosophy. This entails a move from compartmentalized approaches, to "intermedial" ones where "old and new, mechanical and electronic, analogue and digital, word-based and image-based media" (3) can be read together. This intermedial perspective proves most valuable in a film like The Hateful Eight where truth and artifice intermix and result in highly theatrical moments, where representation can never be ideal and it is instead generated by the viewing audience. This approach resonates with Erika Fischer-Lichte's idea of theatricality in media, according to which "A represents X while $S$ looks on" $(1992,7)$, hence emphasizing the importance of the audience.

Both Othello and The Hateful Eight consist of five parts or acts, pivot largely on fateful female characters, and sketch villains that cause tragic ends. Notably, they contain violent scenes that, in Barthes' words, not only "unsettle" and "discomfort" but also make the audience question the nature of the quotidian reality. Exploring connections between Tarantino and Shakespeare cannot be an entirely new territory. For example, Tarantino's fascination with popular culture and classical literature has attracted the attention of many scholars. His affiliations with postmodernism results in his "blending of high culture (Shakespeare, Beethoven, Wagner, Citizen Kane, 81/2) and low culture (comics, exploitation films)," which, in effect, makes "both an aesthetic and a political statement" (Roche 2018, 290). This political message, in turn, expresses itself in the representation of race, wherein people of color appear to be the target of malignancy and bias. In his Race on the QT, Adilifu Nama sees Tarantino as 
a "complex screenwriter and director who questions America's traditional notions of race, ethnicity, and gender" (2015, 10). Along the same lines, David Roche spotlights this engagement in The Hateful Eight and asserts that in the film it is "race which [...] will be the decisive issue in the outcome" $(2018,32)$. Othello, likewise, has drawn the attention of critical race theorists, as it has "shaped racial understanding in a range of ways unthinkable to Shakespeare and his original audiences" (Smith 2010, 28) as well as later theatrical productions. For instance, when Paul Robeson took the role, he stated that "Othello in the Venice of that time was in practically the same position as a colored man in America to-day" (cited in Vaughan 2012, 119).

Both works also revel in depicting moments where deception and misinformation run hand in hand. In his interaction with Othello, Iago is like an Elizabethan essayist, as Catherine Belsey appropriately states, one who is "succinct, laconic, dispassionate" (2008, 157). This way he manages to "colonize Othello's mind [and] claim territory for his own" (Genster 1990, 789). Thus, Othello is the "victimized self whose narrative has been usurped from him" (Robison 2011, 70). Likewise, in The Hateful Eight, characters constantly bicker and fight over reality, turning the saloon into a "theatre in which things aren't what they seem" (Brody 2016, 4). The examination of deceit becomes more complex when we consider The Hateful Eight in comparison with Tarantino's other movies. For example, if Inglourious Basterds (2009) and Django Unchained (2012) offer "visual counter-narratives to history" in which the other or the people of color might fictively reign triumphant, The Hateful Eight aims to "superimpose new images over old ones" (Robbins 2016, 369) and question the nature of reality itself altogether.

The similarities between the two, however, move beyond moments of untruth and manipulation. A hypertrophy of images appears to be the product of conflicting narratives forged by characters in both works. This phenomenon results in contorted realities and political 
violence. To further analyze this connection between the two works and artists, this essay builds on the philosophical ideas of Jean Baudrillard, particularly his theories on the issue of reality, strategies of evil, crime, and even spirit of terrorism. Tarantino is noted for his metafictional and self-reflexive films that tie together explicitly political, philosophical, and literary texts, while aiming for broader meanings and interpretations. This essay thus explores the thematic and structural relations of The Hateful Eight to Shakespeare's play, as a likely influence. Reading Shakespeare, on the other hand, in conversation with the visual culture of Tarantino's movie can enable us to re-examine the mechanism through which hyperreal narratives pervade individual quests for power and political subordination. The critical rigor of Baudrillard's thoughts, in this vein, enables the essay to provide a solid understanding of the possible relations between the two works and their contexts.

\section{Hyperreal Effects in Othello and The Hateful Eight}

Despite their influence, Baudrillard's thoughts have sometimes been regarded shallow and inaccurate. He has been called a nihilist and a skeptic. His early writings did not earn him much fame, despite having a serious interventionist tone. It was not until the 1970s and 1980s that the English translation and publication of his short yet provocative books in New York Semiotext(e) helped him became the center of much attention. His Simulacra and Simulation (1981) along with In the Shadow of Silent Majorities (1982) paved the way to meet his critical height. The western philosophical tradition now was ready to draw on concepts like "simulation", "simulacra" and "hyperreality". These were the terms that led him to launch a consistent effort to chart and theorize what happens to the idea of 'reality' in western cultures. Saussure's triad of the signifier, signified, and referent shape the roots of Baudrillard's 
formulations. The exception, though, lies in while Saussure's referent presents an outside-ofthought reality, in a hyperreal condition, the referent posits its own non-reality-the artifice replaces the real. Baudrillard's hyperreality has provided a fresh perspective for many to reexamine their accounts of events like Watergate scandal or understanding of Disneyland as fantastic representations of reality. Not only do these examples help us reshape our perceptions, but also they create the basis of how Baudrillard defines the notion of simulation and hyperreality. He believes that both-Disneyland and Watergate-grapple with the operations of hyperreality, "concealing that reality no more exists outside than inside the limits of artificial perimeter" $(1994,11)$. In fact, both Disneyland and Watergate scandal implicate, in their deepest layers of signification, "the generation [. . .] of a real without origin or reality: a hyperreal" (3). In this way, as Richard Lane asserts, "the model precedes the real" (86). Such an order exceeds the Marxist indication of alienation in the contemporary social and political arena, where the traumatized subject no longer stands against but confronts a world that has absorbed its double. The obscenity of the real thus is what Baudrillard aims to spotlight.

Hyperreality can extend beyond its immediate implications of master events like the above examples, especially when we discuss power relations. To be precise, the third order of simulation (which consists of a complete absorption of reality through the inauguration of a new one) preserves information overload and favors the non-reflective, even the non-person, receiver of knowledge. In a hyperreal network, thus, "information dissolves meaning and dissolves the social, in a sort of nebulous state dedicated not to a surplus of innovation, but, on the contrary, to total entropy" (Baudrillard 1994, 56). This state of entropy deprives individuals of their critical thinking and leads them toward the construction of a hyperreality as a state "more real than the real" (56), a condition that, according to Richard Smith, desires "proximity, transparency, the absorption of the subject" (96). This scheme leads inexorably to the 
generation of a full-blown, taken-to-extreme, hyperreal effect that perfectly covers up the trace of any reality crisis.

Shakespeare's Othello portrays power relations informed by the politics of hyperreal effects. From the outset of the play, Iago - the mastermind behind all the schemes run with the motive of vengeance and jealousy — targets Cassio and plots his downfall. To achieve this, he devises a master plan in which Cassio's merits are rendered doubtable and Othello's choice of Cassio as lieutenant is turned questionable. He uses Rodrigo to pressure Cassio, accuses Desdemona of dishonesty, and even persuades his own wife to be complicit with his crime in order to further his own clothed interests. All the lies, plots, and tricks that he works prove effective and result inescapably in a hyperreality that outruns the reality of the events altogether.

Through the power of disguise, Iago shrewdly escapes notice and manipulates everyone as if acting puppets, and, through one of his monologues, he informs the audience about the centrality of his intentions when he diabolically asserts: "I am not what I am" (1.1.66). He delicately orchestrates his plan for Othello and Cassio, and he wishes to "bring this monstrous birth to the world's light" (1.3.386). He then tactfully hides behind the disguise of morality and virtue to conceal his villainy and veiled interests. Adopting a new identity, he delivers a captivating performance, the perfect execution of which arouses no suspicion about him or his complex scheme. Iago, indeed, does not act nor does he represent; he devilishly simulates. He likens himself to "devils" who in the moment of committing "the blackest [of] sins [. . . / They do suggest at first with heavenly shows / As I do now" (2.3.318-19). Indeed, Iago wreaks havoc on the life and hierarchies of the nobility by the "blackmail of the real" (Baudrillard 1994, 8).

Tarantino's The Hateful Eight presents an almost nonlinear plot imbued with the sense of suspicion and duplicity. For example, Jody and the other gang members distort the reality so 
meticulously that around chapter five, "The Four Passengers," Tarantino resorts to some extradiegetic flashback for narratological clarification. Jody, as an absent presence, appears to be the root of all the simulations that stun the spectator. He remains in the basement until the last scenes of the film, yet everything happens because of his finely-honed master plan: "not to be there, but to see. Like God" (Baudrillard 1996, 38). Like Iago, Jody lies, tricks, and murders in order to release Daisy. He, nevertheless, needs a plan that can cloak reality altogether without leaving any trace for suspicion, and he designs a 'play-within-a-play' scheme that not only distorts the reality, but also affects the consciousness of the audience. Around the midpoint intermission thus, the audience recheck their views on Marquis as the apparent villain and (through an unexpected flashback) explore alternative truths about different characters. Precisely at this point, the narrative pauses, the screen freezes, and Tarantino breaks the film's fourth wall as a voice-over narrator to inform the audience about other underlying realities.

Along with the use of voice-over, Tarantino draws on other filmic experiments to reflect the artifice and refer to the nature of reality as a construct. The application of many rack focus shots with shallow depths of field (especially in the poison scene where the camera focuses on the pot), characters' (particularly Marquis') direct look into the camera (Figure 1), and the use of chapters and headings aim to disrupt the naturalistic features of classical narration in the film. All these are excellent examples of cinematic theatricality, which according to Timothy Corrigan, are used to "expose or critique the false realism of social identities, as well as the commodified realism of movies themselves" $(2012,42)$. Moreover, The Hateful Eight stresses this point in the setting where actions occur in enclosed spaces (alluding to the staginess of the film) and the characterizations which predominately form around stage dialogue. These technical experiments pertain to the "metafictional discourses" and "antimimetic attitude" (Roche 2018, 288) of Tarantino's films in general. Our reading, however, highlights a phase 
beyond the metafictional and antimimetic coordinates of the film, a phase in which reality appears to be far from being in crisis, since an unsuspecting hyperreality has wiped out the traces of the actual truth buried beneath.

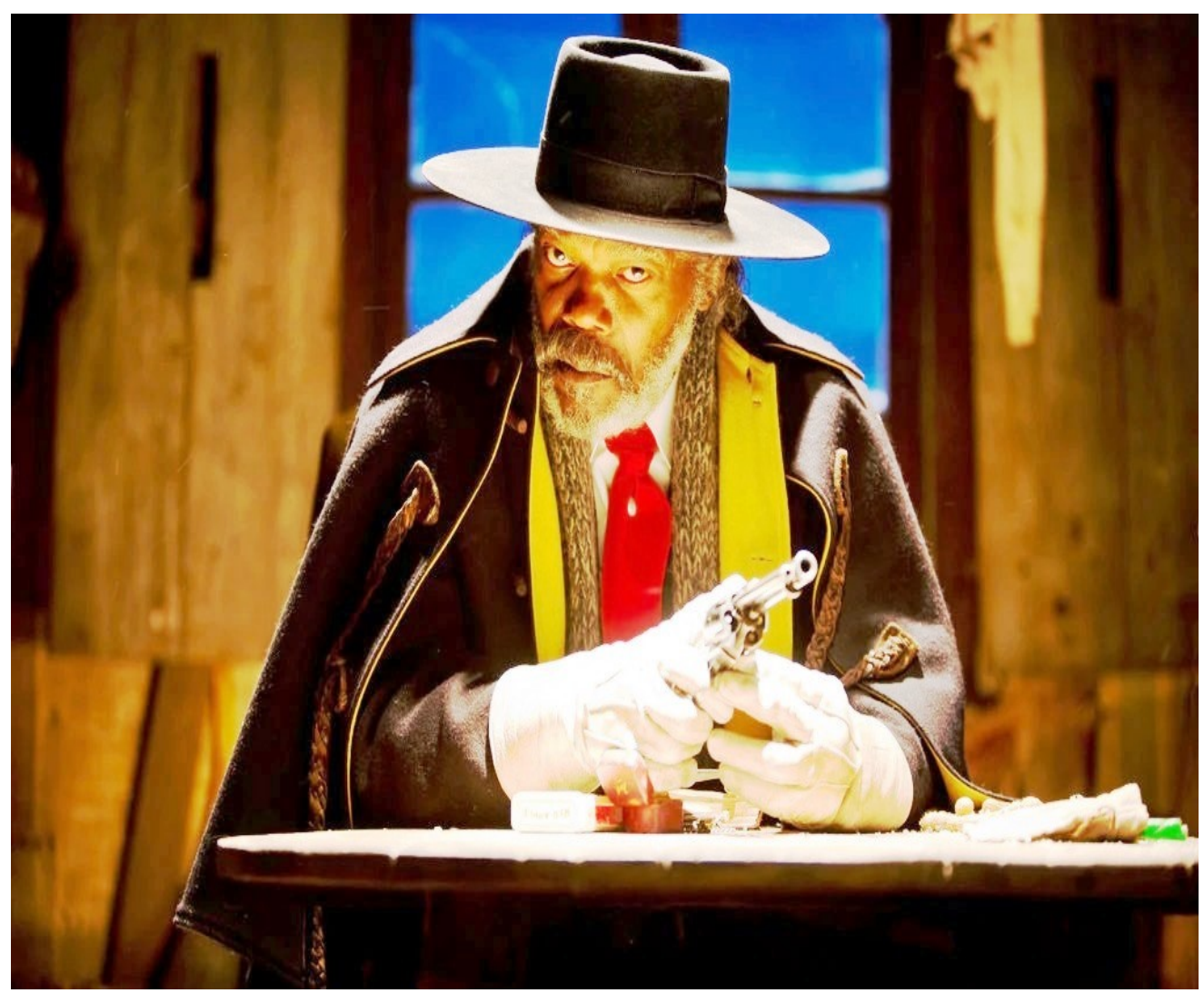

Figure 1: Marquis' direct look into the camera. Screenshot from The Hateful Eight Blu-ray released in 2016 (C) The Weinstein Company.

Shakespeare and Tarantino allude to what the postmodern Baudrillard calls the "Murder of the Real" $(2000,61)$. This differs from Nietzsche's symbolic declaration of the death of Godas a metaphysical concept like reality - since we, as the agents of the crime, have survived it. But, in the case of the murder of the real, we are obliterated along with the reality itself. Indeed reality no longer exists, as it has been displaced with a perfect hyperreality. This hyperreal 
enterprise functions through, what Baudrillard aptly describes, the excess of information and realities:

Let us be clear about this: if the Real is disappearing, it is not because of a lack of it - on the contrary, there is too much of it. It is the excess of reality that puts an end to reality, just as the excess of information puts an end to information, or the excess of communication puts an end to communication. (2000, 65-66)

Iago's plans succeed because he weaves together too many narratives and infuses too much information into Othello's mind. Iago knows that to entangle Othello he should create a knotted form of reality and moral dilemma, and he accomplishes that by "practicing upon his peace and quiet / Even to madness" and "confus[ion]" through a manifold form of "knavery" (2.1.29193). Alessandro Serpieri aptly suggests that Iago's treatment of others "goes beyond the tactics of temptation," representing instead a "contortion of the real" $(2002,139)$. His proves to be more intricate than "a Machiavellian tactic, expressing as it does, under the aegis of a negation of being, not only the game between appearance and reality but also the possible loss of identity" (138). 'Deception' thus appears to be ineffective (if not simplistic) a concept to consider the nature of relations between Iago and others, since a rigorous hyper-reality has surpassed all truth claims insofar as it has resulted in the transformation of their identity, including that of Iago himself. In The Hateful Eight, likewise, Marquis represents an audience whose knowledge of the reality behind events remains limited to the complex narrative forged by the gang members. After all, it is Marquis who uncovers the conspiracy organized by Jody and his crew. However, when he explains his conclusions about the events in the confined saloon, Bob calls him an "imaginative nigger" and mocks him for his "far-fetched nigger theory" (The Hateful Eight). Now Bob's reaction is important since Marquis has deduced all 
those facts from an intricate web of hyperrealities that have replaced the reality of the events; a conclusion that none of the gang members, including Jody, had anticipated, and would have probably understood to be unlikely, or far-fetched, to happen.

In his book Why Hasn't Everything Already Disappeared?, Baudrillard writes about a posthuman era in which the virtual replaces the actual regarding our experience of reality. He suggests that we "speak, then, of the world from which human beings have disappeared" (9). This disappearance takes place when we are deprived of our will and agency; drives that enable us to experience a moment of true decision-making, without precalculations and the influence of external forces. This loss of agency is what individuals confront in a hyperreal structure that always attempts to unify through "the excess of reality" (12). The virtual space of reality that traps Othello adds to his growing sense of paranoia, responding thus "Farewell the tranquil mind! Farewell content" (3.3.349) to Iago's poisonous narratives. The words Iago pours in Othello's ears gradually "set [him] on the rack" (3.3.336), yielding what Iago had sought for long: to see Othello "eaten up with passion" (3.3.392) and unable to differentiate between truth and falsity. The instances of epilepsy Othello experiences signal his surrender in the face of a reality crisis. He therefore resembles his state of mind to an "infected house" (4.1.21), mourning its loss of security and stability.

The undecidable audience in The Hateful Eight ponders on the duality of good and evil until the last scenes of the movie, as the level of violence mounts and more blood is shed. Unlike Shakespeare's play, in which dramatic ironies and Iago's asides inform the audience about the realities behind Iago's narratives, the decision-making body of the viewer in Tarantino's film is significantly compromised or depends largely on Marquis' thoughts and justifications. He poses the real threat to the failing scheme of the gang members, whose plans to free Daisy are 
gradually revealed to the spectator through their constant negotiations with Mannix, particularly led by Daisy who demands that he "Take [his] gun, shoot that nigger dead" (The Hateful Eight). In practice, Tarantino shrewdly uses Marquis-despite his mindless violenceas an instrument to portray how reality and the way we perceive it can be endlessly reexamined.

Challenging the authenticity of the perceived image runs as a thematic concern in Tarantino's movie; an issue he foregrounds via stylistic experimentations. Chief among them is the use of Panavision 65 camera with $70 \mathrm{~mm}$ film stock that provides panoramic, and hence more detailed, shots with extra frame of space added to the sides. This equally gives the audience a wider perspective into the mise en scène as well as actions occurring on the stage. The viewer thus maintains a degree of distance that allows for a far critical stance and an objective look into the dynamics of the stage and character relationship. We can also trace Tarantino's anti-illusionist techniques into deeper layers of the movie. The use of comic scenes (if not gags) amid deep tragic stories, portrayal of double black-and-white protagonists (and friendships) to imply that a post-racial America has yet to come (Mannix and Warren), and the indication of titles, chapters, and sections in the editing process of the movie serve to reflect the artifice itself and emphasize the constructedness of reality (Figure 2). In addition, the occasional appearance of Tarantino himself in person (as a character) or a voice-over in the extradiegetic level of stories blur self-reflectively the boundaries between fiction and reality as they disrupt the classical intensified continuity of narration in film. 


\section{Chapter Four}

\section{Domergue's Got a Secret}

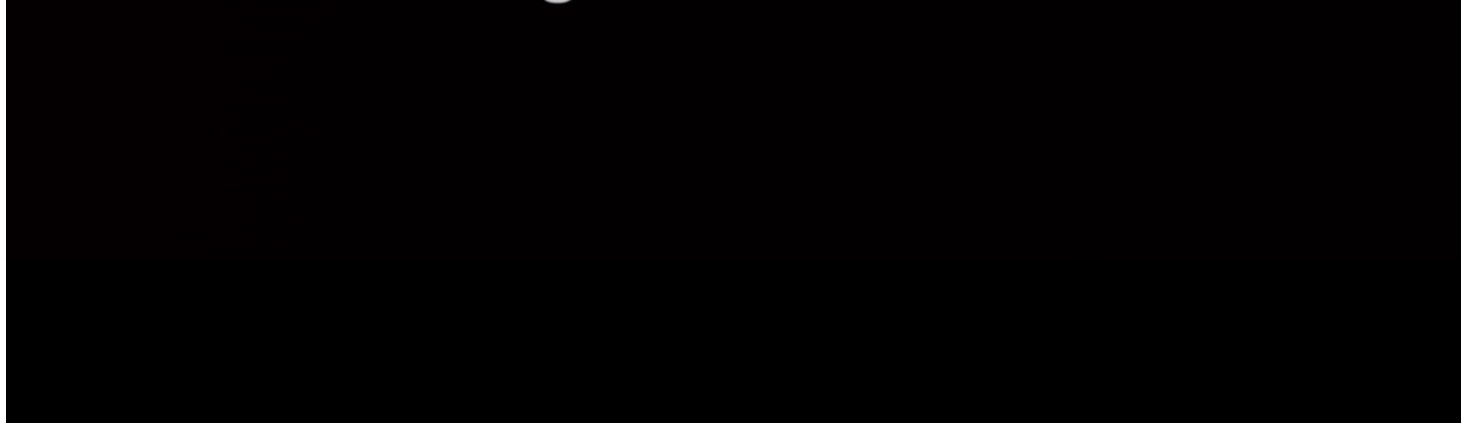

Figure 2: Indication of chapters and sections in the post-production editing process of the film.

Screenshot from The Hateful Eight Blu-ray released in 2016 (C) The Weinstein Company.

\section{Perfect Crime and Spirit of Terrorism}

The incongruity between the world and its appearances helped Baudrillard build further on the notion of hyperreality and draw on what he describes as 'perfect crime,' whose roots can partly be traced to his readings of Nietzsche. The truth/illusion argument espoused by Nietzsche (wherein one falls victim to the ideological illusions promoted by social institutions) leads Baudrillard to frame his thoughts on the similar reality/hyperreality duality. According to him, these two antagonistic forces_-world and appearances, reality and hyperreality — have always existed side by side, without one being ultimately incorporated (and hence reduced) into the other (as is the traditional case with good and evil). He finds this opposition irreconcilable since "the duality is primordial" (Smith 2005, 61); it presents a misfit between the two, and 
hence the perfect crime that always makes both reality and the world vulnerable. In this respect, he acknowledges his indebtedness to Nietzsche in The Perfect Crime, especially on the grounds of illusion and truth:

We oscillate between an illusion and a truth which are each equally unbearable. But perhaps truth is even more unbearable, and we ultimately desire the illusion of the world, even if we take up all the arms of truth, science and metaphysics against it. Our latent truth is that of nihilism, but, as Nietzsche writes, truth cannot be regarded as the highest power. The will to semblance, to illusion, to deception, to becoming, to change (to objective deception) is to be regarded here as deeper, more original, more metaphysical than the will to truth, to reality, to being -- the latter is itself merely a form of the will to illusion. $(1996,9)$

He compares the world's reality to a crime with no clue or a horrible enigma whose appearances are inexchangeable with our thoughts. Barry Smart, in his analysis of Europe/America, draws on this Baudrillardian issue and argues: "Our fate is to be abroad in a universe that refuses to submit to our designs, a universe that continues to be an enigma" $(1993,65)$. Baudrillard also states that because we can never ultimately know the world, we opt for the illusion and, thus, the outright elimination of duality. Therefore, he discusses that "illusion is not simply irreality or non-reality; rather, it is in the literal sense of the word (illudere in Latin) a play upon 'reality' or a mise en jeu of the real" (1987, 42-43). This way the duality remains everlastingly irreducible; none can be melted and transformed into the other. Either truth and reality will surface or hyperrealities will reign triumphantly. Baudrillard considered this mélange of reality and illusion to be a "sacred mystery" (Smith 2005, 154) that remains essentially unresolved. 
The duality in Iago's thoughts - whether or not Othello wants to promote Cassio above him-and his contention that he is worthy of "no worse a place" than lieutenant to Othello (1.1.11) stirs him to play upon reality and create a crushing duality for Othello (whether Desdemona is chaste and honest). Similarly, in The Hateful Eight, Tarantino portrays a world that leaves the audience clueless about the nature of the crimes and their reality. Halfway through the plot, Marquis gives a heartbreaking account of rape and murder of Smithers' son. Marquis informs Smithers that his son, Chester Charles Smithers, was on a "little nigger head huntin"" (The Hateful Eight) along with his comrades when he found himself "at the mercy of a nigger's gun." Momentarily, he manipulates the old general's mind, saying that within the cold weather of Wyoming mountains, he "made him strip" and "told him to start walkin" " until he started begging for a blanket. Having reached the climax of his story, Marquis strikes Smithers with a mortal wound: he had forced the captive to perform oral sex before he killed him. The sense of violence that seeps through Marquis's narrative torments Smithers. Oddly, what overwhelms him is the reliability of Marquis' account. Whether or not he really committed the crime remains unverified. Yet, he deftly arranges such an account so that he can kill the general, and he achieves this by fashioning an illusion, a duality.

This duality manifestly troubles Othello where he decides to narrow everything down to singularity as soon as he meets different accounts of his wife's infidelity. Furious, Othello seeks "proof" and exhorts Iago: "Give me the ocular proof / Or, by the worth of man's eternal soul / Thou hadst been better have been born a dog / Than answer my wak'd wrath!"” (3.3.36164). This generates the first building block of the perfect crime within of the play. This duality petrifies the soon-to-be-murderer Othello. Therefore, he desperately longs for a single reality version of all narratives, which in turn makes him assume a direct line between "to be once in 
doubt / is once to be resolv'd" (3.3.180-181) and "I'll see before I doubt" (3.3.192). Unlike his pigmentation features, Othello's mind resembles that of others; a sheer proof-seeker whose desire to deal with only a single reality verges on monomania. Therefore, torn between the duality of whether his wife is chaste or cheating, and due to Iago's wily provocations, Othello finds himself so helpless that kills his wife partly to wrench himself free from the horrible illusion of a cheating wife.

For Othello, a cheating wife is more bearable than the 'illusion' of such a wife (and hence a crime with no clue), since the former gives him the power to punish his wife and remain poised and respected, but the latter strips him of his leadership features and renders him emasculated both literally and figuratively. In discussing Othello's mental plights, Stephen Greenblatt explains that Desdemona's submission to Othello's sexual drives (not to ignore Iago's role) is what leads Othello to murder her "for it awakens the deep current of sexual anxiety in Othello, anxiety that with Iago's help expresses itself in quite orthodox fashion as the perception of adultery" $(2005,184)$. In other words, the appearances of reality deeply confound Othello and he fails to choose the truth itself. Othello's final sorrow reveals the essence of his struggle with this duality and his ultimate failure of true decision-making: "Whip me, ye devils, From the possession of this heavenly sight / Blow me about in winds, roast me in Sulphur / Wash me in steep-down gulfs of liquid fire! / O Desdemona, Desdemona! Dead! O! O! O!" (5.2.275-79). Baudrillard contends that in our quest to access reality, we ironically form more illusions; hence, Othello's "apt and true" (5.2.176) conjecture about Desdemona aims to capture a single reality as part of an effort to dodge a tormenting illusion. Othello's (doomed) attempts to find the reality only throws him further into the borderland of doubt, symbolically represented in his falling in a trance in Act Four. 
In the case of Tarantino's film, since the raping of his son traumatized Smithers, he takes refuge in shooting Marquis. Doing so, he tries to eliminate the irreconcilable duality of whether Marquis raped his son or not. This is evident in the final moments of chapter two when Marquis cunningly plays upon this duality by teasing him: "you gonna spend the next two or three days ignoring the nigger who killed your boy? Ignoring how I made him suffer?" (The Hateful Eight). Of much importance is also the reaction of Mannix to Daisy's threats and promises. Enchained as a fatal woman, Daisy creates a duality for Chris Mannix: she threatens him that he will not leave the mountain alive "cause when that snow melts, the rest of Jody's gang - all fifteen of 'em - that were waiting in Red Rock are comin' here” (The Hateful Eight). Seeing her own impending doom, she even promises Mannix the bounties on the two dead bodies, Oswaldo and Joe Gage. Mannix finds himself in a terrible duality: What if Daisy is bluffing? What if she is telling the truth? What if she wants to kill him and Marquis both? He thus seeks a single reality version of the narratives around him, that Daisy is lying: "no deal tramp" (The Hateful Eight). Daisy cannot lure Mannix because her verbal communication fails to satisfy his proof-seeking mind. Therefore, he takes Marquis' side who holds the guise of a shrewd, experienced gunman.

Although radical, one possible consequence of hyperreal effects and the violent outcomes manifests itself in a spirit of terrorism, when the crime on reality/illusion comes into full effect. In his essay "The Spirit of Terrorism," Baudrillard refers to such consequences and discusses the issue of terrorism by focusing on $9 / 11$ as one prime example. The core threat of terrorism to the West, according to Baudrillard, originates not from outside of it, but from the (Western) society itself. He thus declares it within the first pages that: 
The fact that we have dreamt of this event, that everyone without exception has dreamt of it—because no one can avoid dreaming of the destruction of any power that has become hegemonic to this degree- is unacceptable to the Western moral conscience. Yet it is a fact, and one which can indeed be measured by the emotive violence of all that has been said and written in the effort to dispel it. $(2003,4)$

Homogenization and globalization, in this regard, can incite the spirit of terrorism. Such an spirit functions as an "abstract limit to globalization, the fact that any system pushed to its furthest extent will begin to reverse upon itself and produce the opposite effects from those intended" (Smith 2005, 215). In fact, Baudrillard finds terrorism non-geographical and nonideological. Terrorism, as he views it, lies at the heart of Western society and necessarily arises from it. This comes from the idea that "the West, in the position of God (divine omnipotence and absolute moral legitimacy), has become suicidal, and declared war on itself" $(2003,7)$. He sees terrorism as an anomaly that occurs to curb the rapid flow of globalization and its unifying intentions. Indeed, when global power allows "no alternative form of thinking," it should be held responsible for "this brutal retaliation," because "terrorism is the act that restores an irreducible singularity to the heart of a system of generalized exchange" (9). It is as though every "machinery of domination secrete[s] its own counterapparatus, the agent of its own destruction" (10). Baudrillard sees the global power as the responsible party behind the core of terrorist desires, "that superpower which, by its unbearable power, has fomented all this violence which is endemic throughout the world, and hence that (unwittingly) terroristic imagination which dwells in all of us" (5). He pays particular attention to the symbolic meaning of the terrorist attacks, believing that they represent a symbolic exchange: an act of terror that mainly aims no more at the system's utter annihilation than ruining its unity and apparent strength. The humiliating power of globalization must itself be humiliated, "it has to 
be made to lose face" (Smith 2010, 26). The symbolic wound proves more effective as it challenges the authority of a system it cannot fully destroy.

In Othello, the Venetian court (the highest governmental office) serves as the bedrock of terrorism-or political violence as was understood in early modern England. A rather deconstructive view of Iago's role might interpret it as a resisting force against the court's unifying power, or his terrorist acts as inevitable consequences of the court's triumph over its subjects. The court demands that everyone act and live within the boundaries that someone else defines; it staves off nearly all opposition, polyphony, and even individuality. In the prologue to her analysis of rhetoric at the court, Catherine Bates describes courtship as "a delicate, fraught, hazardous procedure," since it is "a mode which puts sincerity and deception in a teasing and often inextricable juxtaposition" $(1995,2)$. To emphasize the intricacy of courtly love (and life), Herbert Moller highlights the "courtois behavior" and how "behavioral restraints" (137) determine the boundary of love and chivalry as opposed to unworthiness and charlatanism.

Iago wreaks vengeance against a court that demand everyone be subjected to a hierarchical order. As a war veteran who is denied promotion, Iago revolts against unification, order, and system of (in)justice. He is intrinsically (and perhaps even socially) belittled by the system wherein "Preferment goes by letter and affection" (1.1.36), and thus what he feels is a "sense of injured merit," to borrow from Milton's Satan (Book I, line 98). This resentment spurs him to develop an alternative identity through which he deceptively lurks behind the figure of a faithful servant to prey upon the master. Hence, he openly admits, "In following him, I follow but myself" (1.1.59). What torments Iago is, in fact, not merely Othello but "curse of service" (1.1.35), crafted and issued by a monopolizing system that fails to operate based on "old 
gradation" (1.1.37). Iago's targeting of Othello and Cassio can be interpreted as a symbolic act against a form of monarchical leadership and tyranny. A hidden monopolizing force is also present in The Hateful Eight where Marquis fights against a white-dominated world, Daisy grapples with a male-dominated ideology, and Jody runs from a Lincolnesque system of law. Put briefly, terrorism in both works comes from the heart of a unifying power, a Pandora box, which excites resistance, bloodshed, and murder.

In Othello, the court and its hierarchical codes and rules bar Iago, and, in retaliation, he urges Roderigo to "rouse" (1.1.69) Desdemona's father (a prominent courtier) to symbolically challenge courtly values as well as expose its latent debauchery. This is the first time in the play that Iago reveals his intentions of wounding a courtier by attempting to "Poison his delight" (1.1.69), even if "his joy be joy / Yet throw such chances of vexation on't" (1.1.7273). In the same fashion, Jody attempts to rescue his sister to symbolically discredit the law. Jody's final words with his gang members resemble the mutual commitment of a captain and his band of followers who fight for a cause, that is saving a prisoner from a ruthless (John Ruth) guardian:

\footnotetext{
Now remember, it doesn't matter if we have four men or forty we are still gonna be facing John Ruth chained to my sister with a pistol pointed at her belly. Now killin' that fella 'fore he kills my sister ain't gonna be easy, but you better believe that's exactly what we gonna do. So, the name of the game here is patience. (The Hateful Eight)
}

In his Fatal Strategies, Baudrillard discusses that for some societies security's cost is more or less "to generalize terror at all levels" $(2002,196)$. This way, the spirit of terrorism will be internalized and a paradox will emerge: there will be no exchange between the terrorists and 
society, since the social itself has become an instigator of terrorism. In Othello, Iago's mischiefs are deep-rooted in most of the characters. If Iago is knavish, inhumane, egotistic, and untruthful, Emilia spies on Desdemona, Cassio teases and tantalizes Bianca, Rodrigo pursues his lust, Brabantio forsakes his daughter, Desdemona cheats on her father, and Othello commits murder. Daisy, in the same fashion in The Hateful Eight, is surrounded by the agents of authority and power - a bounty hunter, a former Union cavalry officer, a new sheriff, and an old general, most of whom are closely associated with law and government. The bounty hunter in The Hateful Eight (John Ruth) acts, talks, and thinks like those he chases; he reminds us of the 'bad guy chases bad guys' rather than 'the good cop chases bad guys'. He treats women like slaves ("When I elbow you real hard in the face, that means shut up" (The Hateful Eight)), can kill senselessly ("if you come back with anything else but a guitar, my pistol plays a tune: 'Domergue's Death March"'), and tends to exclusively exploit everyone in his own favor ("I am going to take you gun, son"). Likewise, almost any other character in the movie contributes to the terrorist-like acts and instigates terrorist thoughts and moves. When there is fight for ultimate power or mass distribution of an ideology, as is evidently the case in The Hateful Eight and Othello, there follows inevitably the phase of simulation and hyperreality, which is supraindividual and non-voluntaristic. It does not entail traditional ethical charges; it occurs based on a cause-and-effect system.

John Ruth declares that Daisy is wanted for murder, but what we ironically witness is the glaring villainy of those surrounding her. Daisy is nominally the criminal, but commits almost no act of crime, as we see. An oxymoronic theme The Hateful Eight foregrounds is the fostering of terrorism by those guardians of society. We can hardly distinguish the malevolence of those who are supposedly the representatives of law (John Ruth, Marquis, Mannix) from 
those characters who are associated with villainy (Daisy, Jody, Bob, Oswaldo, and Gage); even the number of people killed by the bullets of the 'Jody gang' and the 'law gang' are identical (six to six). The Hateful Eight projects a microcosmic world into the screen which, by implication, claims that the difference between the outlaw and the keeper of the law might be no more than the possession of a badge or a title. The Western desire to witness eye-catching events is a key affective tonality in Baudrillard's analysis of terrorism (and its spirit). $\mathrm{He}$ considers terrorist acts like 9/11 to be among one of those events, a type of "spectacular violence" $(1998,174)$ that the West enjoys watching; hence, his famous contention that "At a pinch, we can say that they did it, but we wished for it" $(2003,5)$. Like Othello, in which revenge and violence appear to be the expected outcomes, Tarantino's The Hateful Eight provokes the joy of watching dramatic violence in viewers, which is not only embodied in the slaughterous gunfights, but is also evident in the last scene where we feel a remote satisfaction as Daisy is hanged by Marquis and Mannix.

The links traced in this essay between the modern Tarantino and the classical Shakespeare support the claim that hyperreal effects do not necessarily have to be the product of modern imaged-glutted societies of spectacle, but can arise from the mass dissemination of any ideological statement or social and personal pursuit of power. In this vein, Baudrillard's critical legacy freshly informs our understanding of the cultures that influence the production of works by Tarantino and Shakespeare. A reading of The Hateful Eight in light of the canonical world of Shakespeare stresses also an important side of Tarantino's filmic contribution that owes itself to the appeal of popular culture and its intertextual qualities. This reading simultaneously can offer an alternative interpretation about Shakespeare's play in dialogue with modern critical theories about power and (political) violence. Macbeth and Hamlet, Inglourious Basterds and Reservoir Dogs, among others works, reveal similar social, political, and 
philosophical tendencies and can thus be rich avenues for further comparative discussions. Shakespeare, Tarantino, and Baudrillard, in effect, illustrate in their works the challenging nature of reality as well as the issue of criminality. That is why Shakespeare's voice still resonates after centuries, Tarantino intervenes to goad our consciousness, and Baudrillard challenges our assumptions about questions of truth and authenticity.

\section{BIBLIOGRAPHY}

Adilifu, N. (2015). Race on the QT: Blackness and the Films of Quentin Tarantino. Texas: U of Texas P.

Barthes, R. (1975). The Pleasure of the Text. Trans. Richard Miller. New York: Hill and Wang.

Bates, C. (1995). The Rhetoric of Courtship in Elizabethan Language and Literature. Cambridge: Cambridge UP.

Baudrillard, J. (1987). The Evil Demon of Images. Sydney: The Power Institute of Fine Arts.

Baudrillard, J. (1994). Simulacra and Simulation. Trans. S. Glaser. Michigan: U of Michigan P.

Baudrillard, J. (1996). The Perfect Crime. Trans. C. Turner. London and New York: Verso.

Baudrillard, J. (1998). The Consumer Society: Myths and Structures. California: Sage.

Baudrillard, J. (2000). The Vital Illusion. New York: Columbia UP.

Baudrillard, J. (2002). Fatal Strategies. In M. Poster (Ed.), Selected Writings, (185-206). Cambridge: Polity Press.

Baudrillard, J. (2003). The Spirit of Terrorism. Trans. C. Turner. New York: Verso. 
Baudrillard, J. (2009). Why Hasn't Everything Already Disappeared? Tr. C. Turner. Seagull.

Belsey, C. (2008). Shakespeare in Theory and Practice. Edinburgh: Edinburgh UP.

Brody, R. (2016). "The Hateful Eight: Quentin Tarantino's Playfully Adolescent Filmmaking." The New Yorker, 1 Jan. https://www.newyorker.com/culture/richard-brody/the-hatefuleight-quentin-tarantinosplayfully-adolescent-filmmaking. Accessed 29 Dec. 2019.

Broughton, L. (Ed.). (2020). Reframing Cult Westerns: From The Magnificent Seven to The Hateful Eight. Bloomsbury.

Corrigan, T. (2012). Film and Literature: An Introduction and Reader. London and New York: Routledge.

Fischer-Lichte, E. (1992). Semiotics of Theatre. Trans. J. Gains and D. R. Jones. Bloomington: Indiana UP.

Geiger, J, and K. Littau. (2013). Introduction: Cinematicity and Comparative Media. In J. Geiger and K. Littau (Eds.), Cinematicity in Media History, (1-18). Edinburgh: Edinburgh UP.

Genster, J. (1990). Lieutenancy, Standing in, and Othello. ELH, 57 (4), 785-809.

Greenblatt, S. (2005). The Greenblatt Reader. New Jersey: Blackwell.

Lane, R. J. (2002). Routledge Critical Thinkers: Jean Baudrillard. London and New York: Routledge.

Milton, J. ([1667] 2005). Paradise Lost. Oxford: Oxford UP.

Moller, H. (1959). The Social Causation of the Courtly Love Complex. Comparative Studies in Society and History, 1 (2), 137-163.

Núñez Alberca, A. (2020). Las estrategias del creer en Los ocho más odiados, de Quentin Tarantino. Contratexto, (34), 243-264. 
Robbins, H. (2016). "US HISTORY IN 70 MM - The Hateful Eight (2015). Directed by Quentin Tarantino. The Journal of the Gilded Age and Progressive Era, 15 (3), 368-370.

Robison, M. B. (2011). The Power of Words: Othello as Storyteller. Storytelling, Self, Society, $7(1), 63-71$.

Roche, D. (2018). Quentin Tarantino: Poetics and Politics of Cinematic Metafiction. Mississippi: UP of Mississippi.

Serpieri, A. (2002). Reading the Signs: Towards a Semiotics of Shakespearean Drama. In J. Drakakis (Ed.), Alternative Shakespeares, (121-145). London and New York: Routledge.

Shakespeare, W. ([1604] 2003). Othello. Cambridge: Cambridge UP.

Smart, B. (1993). Europe/America: Baudrillard's Fatal Comparison. In C. Rojek and B. S. Turner (Eds.), Forget Baudrillard? (47-69). London and New York: Routledge.

Smith, E. (2005). William Shakespeare: Othello. Liverpool: Northcote.

Smith, R. G. (2010). The Baudrillard Dictionary. Edinburgh: Edinburgh UP.

Tarantino, Q, director (2015). The Hateful Eight. New York: The Weinstein Company.

Vaughan, A, and V. M. Vaughan. (2012). Shakespeare in America. Oxford: Oxford UP.

Zitzelsberger, F., \& Beyvers, S. E. (2018). Revisionist Spectacle? Theatrical Remediation in Alejandro G. Iñárritu's Birdman and Quentin Tarantino's The Hateful Eight. Iowa Journal of Cultural Studies, 18(1), 3-21. 